\title{
Palladium-mediated synthesis of a new eight-membered heterocycle
}

\author{
Gabriele Bocelli, ${ }^{a}$ Marta Catellani, ${ }^{\text {b* }}$ Federica Cugini, ${ }^{b}$ and Raffaella Ferraccioli ${ }^{\mathrm{c}}$ \\ ${ }^{a}$ Centro di Studio per la Strutturistica Diffrattometrica del C.N.R., \\ Parco Area delle Scienze, 17/A, I-43100 Parma, Italy \\ ${ }^{b}$ Dipartimento di Chimica Organica e Industriale, Parco Area delle Scienze, 17/A, \\ I-43100 Parma, Italy \\ ${ }^{c}$ Centro di Sintesi e Stereochimica di Speciali Sistemi Organici CNR, Via Golgi 19, \\ I-20133 Milano, Italy \\ E-mail: marta.catellani@unipr.it
}

\section{Dedicated to Professor Marcial Moreno-Manas on the occasion of his $60^{\text {th }}$ birthday (received 24 Jan 02; accepted 25 Mar 02; published on the web 02 Apr 02)}

\begin{abstract}
The eight-membered heterocycle 3 has been prepared in 94\% isolated yield starting from phenylnorbornylpalladium chloride dimer, $o$-iodoacetanilide and carbon monoxide in DMF at room temperature. Compound $\mathbf{3}$ has been unequivocally characterized by X-ray single crystal diffraction. Formation of $\mathbf{3}$ must involve coordination of the amido group to palladium which prevents ring closure to a hexahydromethanotriphenylene derivative.
\end{abstract}

Keywords: Palladium catalysis, eight-membered heterocycle, o-iodoacetanilide, carbon monoxide

\section{Introduction}

The class of azocines, ${ }^{1}$ eight-membered cyclic amides, has been little studied. Hypotensive properties have been reported for a class of $N$-substituted[c,f]dibenzazocine derivatives. ${ }^{2}$ 6Methoxytribenzazocine has been prepared by Paquette and coworkers. ${ }^{3}$ Palladium involving procedures based on different strategies have been recently reported. ${ }^{4}$ As part of our continuing interest in the synthesis of cyclic compounds ${ }^{5}$ as well as in the reactivity of arylnorbornylpalladium complexes, ${ }^{6}$ we have worked out the preparation of a new benzazocine derivative: 5-acetyl-10b,11,12,13,14,14a-hexahydro-11,14-methanotribenz [b,d,f]azocin-6-one.

\section{Results and Discussion}

Compound 3 was obtained in almost quantitative yield by reaction of phenylnorbornylpalladium chloride dimer ${ }^{7}$ with $o$-iodoacetanilide and carbon monoxide in the presence of $\mathrm{K}_{2} \mathrm{CO}_{3}$ as a base 
and in DMF as solvent. The reaction was run, first under nitrogen for $6 \mathrm{~h}$ at room temperature, then under atmospheric pressure of carbon monoxide (Eq. 1). Compound 3 was isolated as a white solid, in 94\% yield by flash chromatography. Colourless crystals, suitable for X-ray analysis, were obtained by recrystallization from a solution of hexane-methylene chloride. The crystal structure determination was essential to unequivocally characterise compound $\mathbf{3}$, spectroscopic methods alone being insufficient to prove the presence of an eight-membered ring.

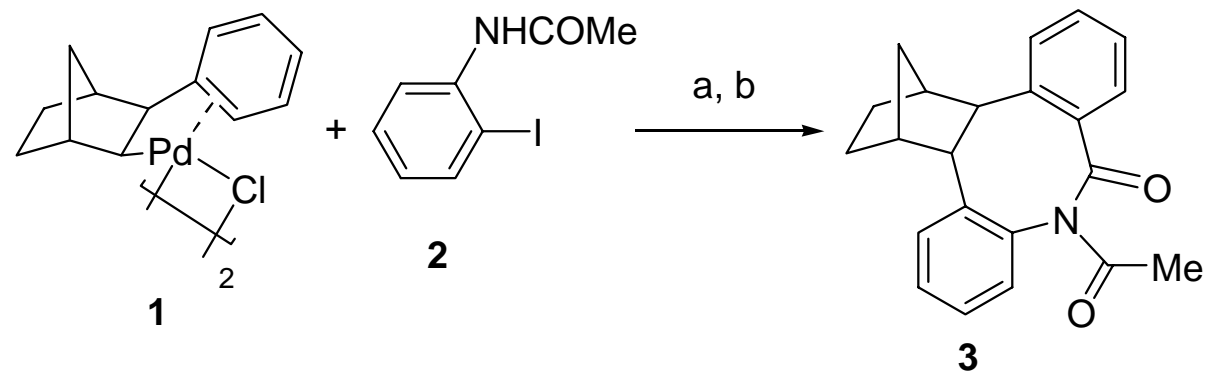

(a) 6 h. (b) under $\mathrm{CO}, 24 \mathrm{~h} \mathrm{~K}_{2} \mathrm{CO}_{3}$, DMF, under $\mathrm{N}_{2}$, room temperature

The crystal structure is reported in Figure 1. The norbornyl moiety and the aromatic ring, which are planar within 0.011(6) $\AA$, show normal geometries and their bond distances and angles do not deviate significantly from the expected values. The eight-membered ring is arranged in a boat conformation with four atoms (C1, C6, C14, N16) lying almost in a basal plane and the other four forming the bow (C8, C13) and the stern (C20, C25); consequently the two C8-C13 and C20-C25 aromatic rings are located on the same side with respect to the basal plane and their mean planes form a dihedral angle of $118.7(2)^{\circ}$. In the crystal the molecules are joined by normal van der Waals interactions and the shortest contact is $\mathrm{H} 10 \cdots \mathrm{O} 18^{\mathrm{i}}=2.44(8) \AA, \mathrm{i}=x, y-1, z$.

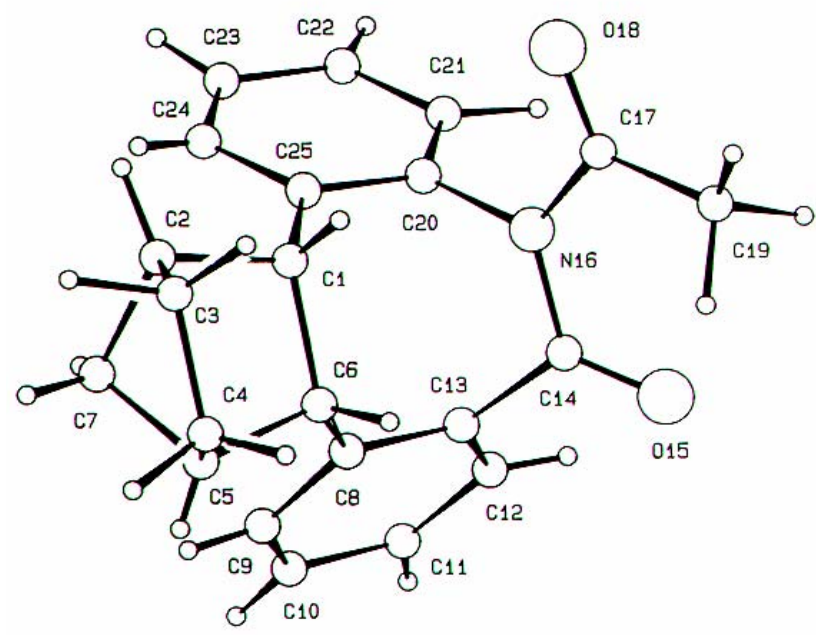

Figure 1. Projection of compound 3 with arbitrary numbering scheme.

The proposed pathway for the formation of the cyclic amide is described in Scheme 1. 


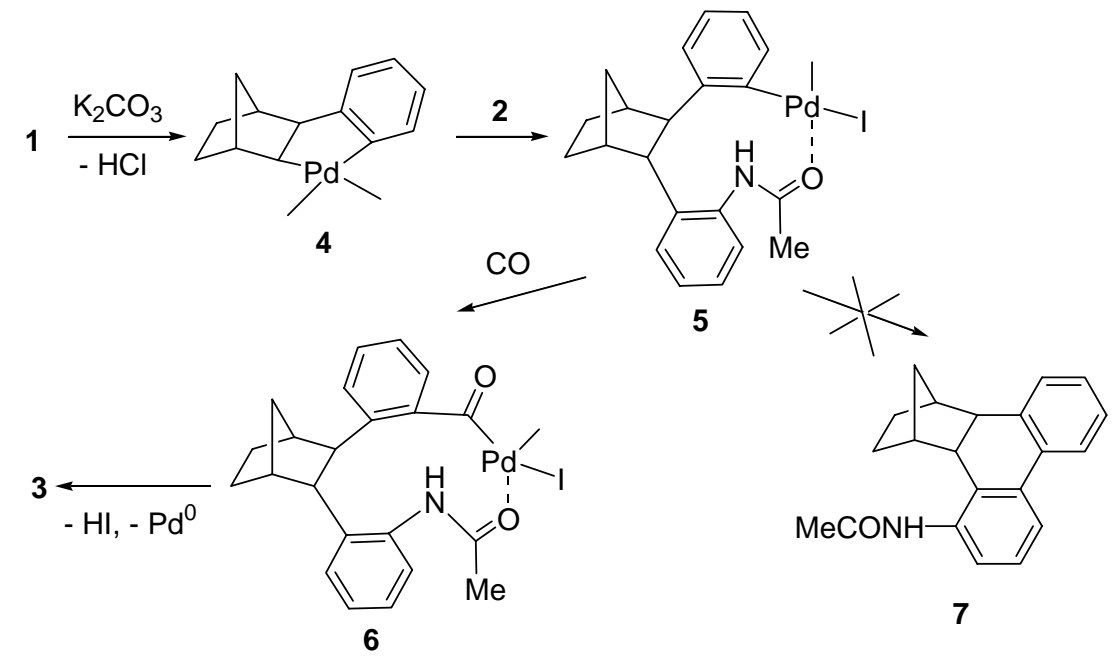

Scheme 1. Proposed mechanism for the formation of compound 3.

Formation of the five-membered alkylaromatic palladacycle $\mathbf{4}$ from complex $\mathbf{1}$ readily occurs in the presence of a suitable base such as $\mathrm{K}_{2} \mathrm{CO}_{3}$ in DMF as solvent. The intermediacy of metallacycle 4 has been previously proposed. ${ }^{8}$ The subsequent reaction with $o$-iodoacetanilide leads to complex $\mathbf{5}$ which is able to insert carbon monoxide giving rise to species $\mathbf{6}$. The cyclic amide 3 results from the attack of the $\mathrm{NH}$ group to the acylpalladium complex $\mathbf{6}$. The reaction of complex 4 with $o$-iodoacetanilide probably involves oxidative addition of the latter to the palladacycle, leading to a palladium(IV) metallacycle which in its turn gives 5 by reductive elimination. Palladium(IV) complexes $^{9}$ resulting from oxidative addition of alkyl halides to alkylaromatic palladacycles have been previously reported by us. ${ }^{10}$

The entire process offers a new way to gain access to a rare class of heterocyclic eightmembered rings in high yield through a recently found methodology involving palladacycle formation. ${ }^{6}$ In view of the knowledge of the behaviour of alkylaromatic palladacycles mostly acquired in the authors' laboratory ${ }^{6,11}$ the results now obtained appear rather surprising in that complex 5 does not form a six membered ring, as shown in compound 7, by coupling the two aryl groups ${ }^{11}$ and allows carbon monoxide insertion leading to the acylpalladium complex 6 . Therefore we assume coordination of the amido group to account for the behaviour of complex 5. ${ }^{12}$ The reaction is tolerant of meta and para substituents in both aromatic rings.

The observation that an amido group can successfully interfere with the previously described ring closure, ${ }^{11}$ has a synthetic potential as well as mechanistic implications.

Thus far a direct attack of the NH group to the arylpalladium bond, which would lead to the formation of a seven-membered ring, could not be obtained even working under conditions of strong basicity and in the presence of chelating ligands, according to procedures described in the literature. ${ }^{13}$ The failure to close this ring, while the eight-membered one was readily formed, is likely due to steric hindrance in the congested transition state.

In conclusion, we have achieved the synthesis of a new benzazocine derivative by taking advantage of the unexpected behaviour of the species 5, resulting from the reaction of an alkylaromatic palladacycle with an $\boldsymbol{o}$-iodoacetanilide. Further extension of this concept is under study. 


\section{Experimental Section}

General Procedures. Starting materials were commercial products and were used without further purification. Complex 1 was prepared according to the literature. ${ }^{7}$ DMF was dried over 4 $\AA$ molecular sieves and stored under nitrogen. Reactions were carried out under nitrogen using Schlenk techniques. Analytical TLC was performed using silica gel plates (Merck). GLC analyses were run with a Carlo Erba HRGC 5300 instrument equipped with a $30 \mathrm{~m}$ long capillary column (SE-30 as the stationary phase). Flash chromatography was carried out with silica gel 60 (ICN Silica 32-63) using hexane-ethyl acetate as eluent. Melting points were determined on an Electrothermal apparatus and are uncorrected. ${ }^{1} \mathrm{H}$ - and ${ }^{13} \mathrm{C}-\mathrm{NMR}$ were acquired in $\mathrm{CDCl}_{3}$ at $20^{\circ} \mathrm{C}$ using the solvent as reference on a Bruker AC-300 spectrometer at 300.1 and $75.4 \mathrm{MHz}$, respectively. Infrared spectra were obtained with a Perkin-Elmer 298 FT-IR spectrophotometer. Mass spectra ( $\mathrm{m} / \mathrm{z}$, relative intensity \%) were performed with a Finnigan Mat SSQ 710 instrument working at $70 \mathrm{eV}$ ionisation energy. Elemental analysis was performed using a Carlo Erba EA 1108-Elemental Analyzer.

5-Acetyl-10b,11,12,13,14,14a-Hexahydro-11,14-methanotribenz[b,d,f]azocin-6-one (3). Solid $\mathrm{K}_{2} \mathrm{CO}_{3}$ (14 mg, $0.1 \mathrm{mmol}$ ) was introduced under nitrogen into a Schlenk-type flask containing a DMF solution ( $2 \mathrm{~mL}$ ) of phenylnorbornylpalladium chloride dimer $\mathbf{1}^{7}$ (31 $\mathrm{mg}, 0.05 \mathrm{mmol}$ ). The resulting mixture was stirred for few minutes until the color changed to light purple. A DMF solution $(1 \mathrm{~mL})$ of $o$-iodoacetanilide $(26 \mathrm{mg}, 0.1 \mathrm{mmol})$ was added and stirring was continued for 6 hours at room temperature. Nitrogen was replaced by carbon monoxide at atmospheric pressure and the reaction was kept at room temperature under stirring for additional $24 \mathrm{~h}$. The solution was diluted with water $(20 \mathrm{~mL})$ and extracted with diethyl ether $(3 \times 10 \mathrm{~mL})$. The combined organic phase was dried over anhydrous $\mathrm{Na}_{2} \mathrm{SO}_{4}$ and the solvent was removed under reduced pressure. The resulting crude was purified by flash chromatography on silica gel using a 7:3 mixture of hexane-ethyl acetate as eluent. Compound 3 (31 mg, 94\%) was isolated as a white solid which was recrystallized from hexane to give bright needles of mp ${ }^{149-151 ~}{ }^{\circ} \mathrm{C}$; ${ }^{1} \mathrm{H}-\mathrm{NMR} \delta$ 7.15-6.96 (7H, m), 6.90 (1H, d further split, $J=7.4 \mathrm{~Hz}), 3.31(1 \mathrm{H}, \mathrm{dd}, J=9.8,1.1 \mathrm{~Hz}), 3.08(1 \mathrm{H}$, dd, $J=9.8,1.6 \mathrm{~Hz}), 2.83(3 \mathrm{H}, \mathrm{s}), 2.81(2 \mathrm{H}, \mathrm{m}), 1.89-1.78(3 \mathrm{H}, \mathrm{m}), 1.56$ (1H, d quintets, $J=10.0$, $1.6 \mathrm{~Hz}), 1.53-1.45$ (2H, m); ${ }^{13} \mathrm{C}-\mathrm{NMR} \delta$ 173.5, 172.6, 140.1, 138.2, 138.0, 137.4, 129.9, 128.9, 128.8, 126.7, 126.1, 126.0, 125.7, 124.8, 50.7, 50.2, 40.0, 39.1, 35.7, 30.2, 29.4, 27.5; IR (KBr) v 1724, $1638 \mathrm{~cm}^{-1}$; MS (EI, $70 \mathrm{eV}$ ): $\mathrm{M}^{+} 331$ (12), m/z 288 (100), 264 (40). Anal. calcd. for $\mathrm{C}_{22} \mathrm{H}_{21} \mathrm{NO}_{2}$ : C, 79.72; H, 6.39; N, 4.23. Found: C, 80.44; H, 6.43; N, 4.26.

$X$-Ray analysis

The crystal data and pertinent details of the experimental conditions are summarized in Table 1. The Lorentz and polarisation effects were corrected during the data reduction procedure. ${ }^{14}$ The structure was solved by direct methods with SIR9 $7^{15}$ and refined by anisotropic full-matrix leastsquares with SHELX93. ${ }^{16}$ All hydrogen atoms were located in a $\Delta \mathrm{F}$ map and refined isotropically. Table 2 reports selected bond distances $(\AA)$ and bond angles $\left(^{\circ}\right)$. 
Table 1. Crystallographic data and experimental information for compound 3

\begin{tabular}{|c|c|c|}
\hline Formula & $\mathrm{C}_{22} \mathrm{H}_{21} \mathrm{NO}_{2}$ & \\
\hline Formula weight & 331.41 & \\
\hline \multicolumn{3}{|l|}{ Crystal: } \\
\hline Shape & prism & \\
\hline Dimensions (mm) & $0.17 \times 0.23 \times 0.29$ & \\
\hline Crystal system & Triclinic & \\
\hline Space group & $\mathrm{P}-1$ & \\
\hline \multicolumn{3}{|l|}{ Cell Constants: } \\
\hline a $(\AA)$ & $9.622(2)$ & \\
\hline b $(\AA)$ & 10.547(3) & \\
\hline с $(\AA)$ & $9.405(3)$ & \\
\hline$\alpha\left({ }^{\circ}\right)$ & 116.06(4) & \\
\hline$\beta\left({ }^{\circ}\right)$ & $94.29(3)$ & \\
\hline$\gamma\left({ }^{\circ}\right)$ & $80.31(2)$ & \\
\hline Cell volume $\left(\AA^{3}\right)$ & $845.18(5)$ & \\
\hline Formula units & 2 & \\
\hline$F(000)$ & 352 & \\
\hline $\mathrm{D}_{\text {calc }}\left(\mathrm{g} \mathrm{cm}^{-3}\right)$ & 1.30 & \\
\hline$\mu_{\text {calc }}\left(\mathrm{cm}^{-1}\right)$ & 6.19 & \\
\hline \multicolumn{3}{|l|}{ Cell determination: } \\
\hline $\mathrm{n}^{\mathrm{o}}$ of reflections & 47 & \\
\hline$\theta$ range $\left(^{\circ}\right)$ & 7.1-33.9 & \\
\hline Temperature & room & \\
\hline Diffractometer & Enraf Nonius CAD4 & \\
\hline Radiation, wavelength $(\AA)$ & CuKa, 1.5418 & \\
\hline Standard reflection, step & one, every 100 & \\
\hline Decay of standard & none & \\
\hline Reflections measured & 3159 & \\
\hline Reflections observed [I>2 $\sigma(\mathrm{I})]$ & 1828 & \\
\hline$\theta$ range $\left({ }^{\circ}\right)$ & 3-70 & \\
\hline Indices range: $\mathrm{h}, \mathrm{k}, \mathrm{l}$ & $-11 / 11,-12 / 11,0 / 11$ & \\
\hline No. of refined parameters & 311 & \\
\hline R (obs. Refl.) & 0.048 & \\
\hline R (all refl.) & 0.080 & \\
\hline $\mathrm{R}_{\mathrm{w}}$ & 0.16 & \\
\hline Weights & $\mathrm{w}=1 . /\left[\sigma^{2} \mathrm{~F}_{\mathrm{o}}^{2}+(0.102 \mathrm{P})^{2}\right]$ & \\
\hline$\Delta \rho_{\min / \max }$ & $-0.21 / 0.21$ & \\
\hline Source of structure factors & $\begin{array}{l}\text { Intern. Tables for } \\
\text { Crystallography }^{18}\end{array}$ & X-Ray \\
\hline
\end{tabular}


Table 2. Selected bond distances $(\AA)$ and bond angles $\left(^{\circ}\right)$

\begin{tabular}{lllcll}
\hline C1 - C6 & 1.589 & ( 9) & $\begin{array}{c}\text { C13 - } \\
\text { C14 }\end{array}$ & 1.507 & (12) \\
C1 - C25 & 1.505 & ( 8) & $\begin{array}{c}\text { C14 - } \\
\text { N16 }\end{array}$ & 1.407 & ( 9) \\
C6 - C8 & 1.518 & ( 7) & $\begin{array}{c}\text { N16 - } \\
\text { C20 }\end{array}$ & 1.452 & ( 8) \\
C8 - C13 & 1.401 & (10) & C20 - & 1.390 & (10) \\
& & & C25 \\
\hline
\end{tabular}

\begin{tabular}{llllllll}
\hline C6 - C1 - C25 & 113.7 & (5) & C14 - N16 - C20 & 117.8 & (5) \\
C1 - C6 - C8 & 115.6 & (5) & N16 - C20 - C25 & 120.3 & (5) \\
C6 - C8 - C13 & 121.3 & (6) & C1 - C25 - C20 & 118.6 & (5) \\
C13 - C14 - N16 & 114.2 & (5) & & & & \\
\hline
\end{tabular}

\section{Acknowledgements}

We thank Ministero Università e Ricerca Scientifica (Progetto Nazionale di Ricerca) and National Research Council for finantial support. Mass and NMR facilities have been provided by Centro Interfacoltà di Misure of the University of Parma.

\section{References}

1. Rodd's Chemistry of Carbon Compounds; Coffey, S., Ed.; Elsevier: Amsterdam, $2^{\text {nd }}$ Edn; 1979; Vol. IV, Part K, p 399.

2. Casadio, S.; Pala, G.; Crescenzi, E.; Marazza-Uberti, E.; Coppi, G.; Turba, C. J. Med. Chem. 1968, 11, 97.

3. Paquette, L. A.; Anderson, L. B.; Hansen, J. F.; Lang, S. A., Jr.; Berk, H. J. Am. Chem. Soc. 1972, 94, 4907.

4. (a) Gibson (née Thomas), S. E.; Guillo, N.; Middleton, R. J.; Thuilliez, H.; Tozer, M. J. J. Chem. Soc. Perkin Trans. 1 1997, 447. (b) Gibson (née Thomas), S. E.; Jones, J. O.; McCague, R.; Tozer, M. J.; Whitcombe, N. J. Synlett 1999, 954. (c) Ali, B. M.; Vasapollo, G.; Scarpa, A.; Mele, G. $218^{\text {th }}$ ACS National meeting, New Orleans, LA, August 1999, Abstracts 59.

5. (a) Bocelli, G.; Catellani, M.; Chiusoli, G.P.; Cugini, F.; Lasagni, B.; Neri Mari, M. Inorg. Chim. Acta 1998, 270, 123. (b) Bocelli, G.; Catellani, M.; Cugini, F.; Ferraccioli, R. Tetrahedron Lett. 1999, 40, 2623. (c) Catellani, M.; Cantucci, C.; Cementano, G.; Ferraccioli, R. Synlett 2001, 803. 
6. (a) Catellani, M.; Frignani, F.; Rangoni, A. Angew. Chem., Int. Ed. 1997, 36, 119. (b) Catellani, M.; Cugini, F. Tetrahedron 1999, 55, 6595. (c) Catellani, M.; Motti, E.; Minari, M. Chem. Commun. 2000, 157. (d) Catellani, M.; Motti, E.; Baratta, S. Org. Lett. 2001, 3, 3611.

7. Horino, H.; Arai, M.; Inoue, M. Tetrahedron Lett. 1974, 647.

8. Catellani, M.; Chiusoli, G. P. J. Organomet. Chem. 1988, 346, C27.

9. Canty, A. J. In Comprehensive organometallic chemistry II; Abel, E. W.; Stone, F. G. A.; Wilkinson, G., Eds; Pergamon: Oxford, 1995; Vol. 9, pp 225-290.

10. (a) Catellani, M.; Mann, B. E. J. Organomet. Chem. 1990, 390, 251. (b) Bocelli, G.; Catellani, M.; Ghelli, S. J. Organomet. Chem. 1993, 458, C12.

11. (a) Catellani, M.; Chiusoli, G. P. J. Organomet. Chem. 1985, 286, C13. (b) Catellani, M.; Motti, E.; Paterlini, L.; Bocelli, G.; Righi, L. J. Organomet. Chem. 1999, 580, 191.

12. (a) Gioria, J. M.; Susz, B. P. Helv. Chim. Acta 1971, 54, 2251. (b) Wayland, B.; Schramm, R. F. Inorg. Chim. 1969, 8, 971.

13. Wolfe, J. P.; Rennels, R. A.; Buchwald, S. L. Tetrahedron 1996, 52, 7525 and references therein.

14. Belletti, D. Gestione on line di diffrattometro a cristallo singolo Enraf Nonius CAD4 con PC. Centro di Studio per la Strutturistica Diffrattometrica del C.N.R. Parma, 1998. Internal report $1 / 98$.

15. Altomare A.; Cascarano G.; Giacovazzo C.; Guagliardi A.; Moliterni A.G.G.; Burla, M.C.; Polidori G.; Camalli M.; Spagna R. 1997. A package for crystal structure solution by direct methods and refinement; Private communication.

16. Sheldrick, G.M. 1997, SHELX97. Program for Crystal Structure Refinement, University of Göttingen, Germany. 